Prof. Nebojša BOJANIĆ, $\mathrm{PhD}^{*}$

Faculty of Criminalistics, Criminology and Security Studies

University of Sarajevo, Bosnia and Herzegovina

UDK - 343.541

Original scientific paper

Received: 02.09.2014.

\title{
Analysis of Quality and Efficiency of Crime Investigation Procedures in Processing the Criminal Act of Rape
}

\begin{abstract}
The paper focuses on the analysis of empirical data related to criminal acts of rape in Bosnia and Herzegovina. The analysis includes cases from three largest cities in Bosnia and Herzegovina, which means that the sample may not be representative, but is certainly illustrative. In this study, the aim of which is to analyse crime investigation and procedural procedures in the process of resolving criminal acts of rape, the author uses the subjective - objective method for the first time. The exploratory data analysis was applied to determine the causal impact of individual manifest indicators (objectively and subjectively determined) of the quality and efficiency of conducted proceedings and actions within the criminal procedures. Furthermore, the functional correlation approach was used between certain individual subjective indicators from the evaluation of professionals and the individual manifest variables objectively determined by the research protocol, which have become the subject of the research: crime scene protection, crime scene investigation and criminal investigation. These analyses were used to determine which actions and operations of criminal procedures signifycantly affect the quality and efficiency of pre-trial criminal investigation work, which is afterward reflected on the trial process and adoption of final court decisions for criminal offenses of rape.

Author finally draws certain conclusions based on the research findings. There is no doubt that properly performed steps of the initial intervention, crime scene inspection, expertise and crime investigation influence the court decision to impose unconditional sanctions such as terms of imprisonment, whereas incomplete activities enhance the likelihood of dropping charges. The final conclusion of the research is that there is a direct correlation between the quality of performed crime investigation procedures in resolving rape crimes and the type of court decision and hence the fairness of the trial.
\end{abstract}

Keywords: rape, crime investigation procedures, crime investigation, crime scene protection, crime scene inspection, expert testimony.

\footnotetext{
*E-mail: nbojanic@fkn.unsa.ba
} 


\section{Introduction}

Ideally, all criminal cases should be processed promptly, thoroughly and efficiently. In reality, however, the criminal acts are at best investigated superficially and the thoroughness with which crime investigating procedures are conducted is influenced by the so-called gravity of the event. From the police aspect, a criminal act of rape may be regarded as an act of low priority in terms of criminal investigation (Marinković, 2012; Popović, 2010). This most frequently happens because rape is not given sufficient significance, due to lack of specialised personnel, time lapse from the event to its being reporting and the like. Limited availability of equipment can induce crime investigators to use less desirable procedures and to eliminate certain steps that would normally be taken. It could also happen that conscientious police officers can unintentionally slow down the procedures, although they offer to take part with best intentions, but are not adequately qualified or may just be curious. Too many persons involved in crime investigating procedures can lead to confusion in task division, wrongfully directed procedures, accidental modification of the crime scene or even loss or destruction of evidence. Due to a great variety of possible situations, crime investigation procedures may fail to provide the desired success. Sex crimes constitute a different group of offences in which the use of special crime investigating procedures is required and in which crime investigating procedures are far more complex than in investigating any other criminal offence in which emotional conditions of the victims are not violated so much as in the case of rape. The properly conducted crime investigating procedures become especially significant in cases where a victim and a perpetrator are the only witnesses to the act that has taken place.

In order to perform crime investigating procedures successfully in resolving rape crimes, the basic prerequisite is to estimate the situation for selecting adequate operative, tactical and evidencing steps and actions and to provide a prognosis based on relevant and reliable information which, according to Vodinelić (1985), represents an instrument that may be used to devise systems of crime prevention and ensure its continuity, acting as bridge in space and time.

Consulting court practice as well as crime investigation and criminal procedure theory, has clearly defined actions within criminal investigations procedures that present the subject matter of this research and which include: crime scene protection, crime scene inspection, crime investigation and expert testimony.

Based on the subject matter of research the basic problem was defined and it comprised the question: What procedures and activities within crime investigating procedures significantly influence the quality and 
efficiency of preliminary investigation and investigative actions which, in turn, bear effect on the trial and making valid court decisions for rape crimes? Special problems that arise from the main problem can be addressed using the following questions: How and to which extent do procedures of crime scene protection, crime scene inspection, crime investigation and expert witnesses influence the overall quality and efficiency of crime investigating procedures used in the case of rape crime? Is there a significant correlation between individual steps and activities within crime investigating procedures which allows for more efficient processing of the rape crime?

Thus the aim of the study was established based on the defined subject matter and the defined problem, the said aim being to find out how individual steps and actions within crime investigating procedures influence successful making of valid decisions for rape crime cases.

The main hypothesis of the study presented in this paper was the following one: the sooner rape crimes are reported and the more efficiently processed in terms of crime investigation they are, the faster their resolving and identification of perpetrators and easier gathering of physical evidence that influence the quality and efficiency of court decisions.

The specific hypothesis was that good quality of criminal investigation processing in cases of reported rapes may be achieved even without conducting crime scene investigation if it can secure valid physical evidence in terms of criminal procedure.

The study ${ }^{1}$ used a sample of 77 valid court cases or files related to criminal acts of rape analysed in the Municipal Courts of Sarajevo and Mostar, Cantonal Court in Sarajevo and the Basic Court in Banja Luka. It should be pointed out that five files from the Municipal Court in Mostar could not be included in the sample, so that the study focused on 72 samples.

\section{Methodological Approach}

The goal of this paper is to extract relevant information from the valid court cases from the Municipal Courts in Sarajevo and Mostar, the Basic Court in Banja Luka, and the Cantonal Court in Sarajevo, pertaining to crime investigating procedures applied in detecting and proving the criminal offence of rape. A special procedure was used to convert the obtained information into data which denoted the type and degree of conducted procedures and actions of specific parts of criminal procedures on the

\footnotetext{
${ }^{1}$ The research findings presented in this paper are an integral part of a research related to the impact of crime investigation procedures in resolving rape crimes performed in by the author for the purpose of writing a doctoral thesis entitled Crime Investigation Procedures in Investigating Rape Crimes in 2007.
} 
categorical and ordinal scales. This primarily involves the activities of crime scene protection, crime scene inspection, expert witnesses, and crime investigation.

This has been a very extensive research involving 71 variables, which were - following the initial processing - recoded so as to contract smaller categorical columns or modalities of ordinal scales, thus obtaining useful information from which the data for descriptive and inferential statistics were drawn. For this topic, 32 variables directly or indirectly pertaining to the conducted crime investigation procedures were selected out of the total number of variables established by the protocol $(\mathrm{N}=71)$. A factor analysis was used to reduce this number to 24 relevant variables including: 3 variables related to crime scene protection, 6 variables related to crime scene inspection, 10 variables related to crime investigation, and 5 variables related to expert testimony. In order to check which specific elements of crime investigating procedures - depending on their poor/good quality - influence the overall quality and efficiency of crime investigation, the following two procedures were carried out:

1) The summing of modalities in which individual steps were used within each element of crime investigation yielded the scales from which it was possible to read whether the incidence of the applied steps was low, medium or high in the protection of crime scene, its inspection, crime investigation, and expertise. In this way, we obtained 4 new composite variables one pole of which indicated absence of any of the relevant procedures, whereas the other pole signified maximum use of (almost) all necessary procedures and steps. These 4 new composite variables thus allowed us to estimate the quality of crime scene protection, crime scene inspection, crime scene investigation, and expertise for each individual case. It is therefore justifiable to treat these 4 new variables as measuring the intensity of implementation of procedures and steps in the abovementioned elements of crime investigating procedures which can be used in the statistical analysis for establishing the existence of functional relations among them, or to double check the existence of causal effect of individual variables on the overall evaluation of the quality and efficiency of the preliminary inquiry.

2) Establishing the quality and efficiency of specific elements of crime investigating procedures was performed using another (subjective) procedure, the so-called expert method. Namely, three independent evaluators with excellent knowledge of crime investigating methodology used for resolving rape cases were asked to evaluate each of the court cases on a ten-degree scale and to specifically evaluate the following steps: a) handling the evidence; b) preserving the evidence; c) the quality of photo documentation; d) completeness of the documentation; f) quality of crime 
investigation procedure; g) quality of crime scene inspection; h) minutes of the crime scene investigation; i) identification procedure; $j$ ) crime scene protection; k) medial documentation; 1) quality of the case report.

The three independently obtained marks for every action or step rendered the average grade which was included in the further process of explanatory analyses.

Both of the abovementioned types of newly developed variables (composite variables and variables of average grades) were treated as mediating variables through which the influence of each individual step of crime investigation procedures is reflected more completely on the overall evaluation of the quality and efficiency of the specific case.

\section{Criterion variable}

Bearing in mind the aim of this study, the most important task was to properly establish the criterion variable which in this case should indicate the level of quality and efficiency of implemented crime investigating procedures in each of the court cases analyzed. Following the logic of the selected methodological approach, the criterion variable was established in both the subjective and objective way. Depending on the concordance of the obtained results and the findings of the two different approaches, it will be possible to determine, and with a high degree of reliability at that, the contribution of each individual manifest and composite variable to the overall quality and efficiency of undertaken crime investigating procedures.

1) The subjective way was realised by estimating each individual court file as to what extent the undertaken crime investigating procedures had contributed to the quality and efficiency of reaching the valid decision. Three evaluators independently evaluated the files which constituted the sample in this research by sorting all of them into three categories: 1) not good, 2) partly good, and 3) good ones. Thus we have obtained categorization of all the studied court cases and checked the degree of concordance among the evaluators.

2) The objective way of establishing categorization of the court files involved the use of a cluster analysis which classifies all the cases in an adequate number of homogenous groups (called clusters) based on agreement of characteristics of the performed crime investigating procedures. In this case it was most convenient to use a cluster analysis with three clusters which were maximally different in terms of quality and efficiency of performed crime investigating procedures. This course of action completely ruled out subjectivism which was present in making expert evaluation and objectively classified all the court files in three homogenous groups. 
PREDICTION VARIABLES

Objectively established modalities (research protocol)
MEDIATOR

VARIABLES

Compositely obtained variables by summing up the modalities of manifest variables
CRITERION

VARIABLE

Global evaluation of the quality and efficiency of preliminary investigation and investigation

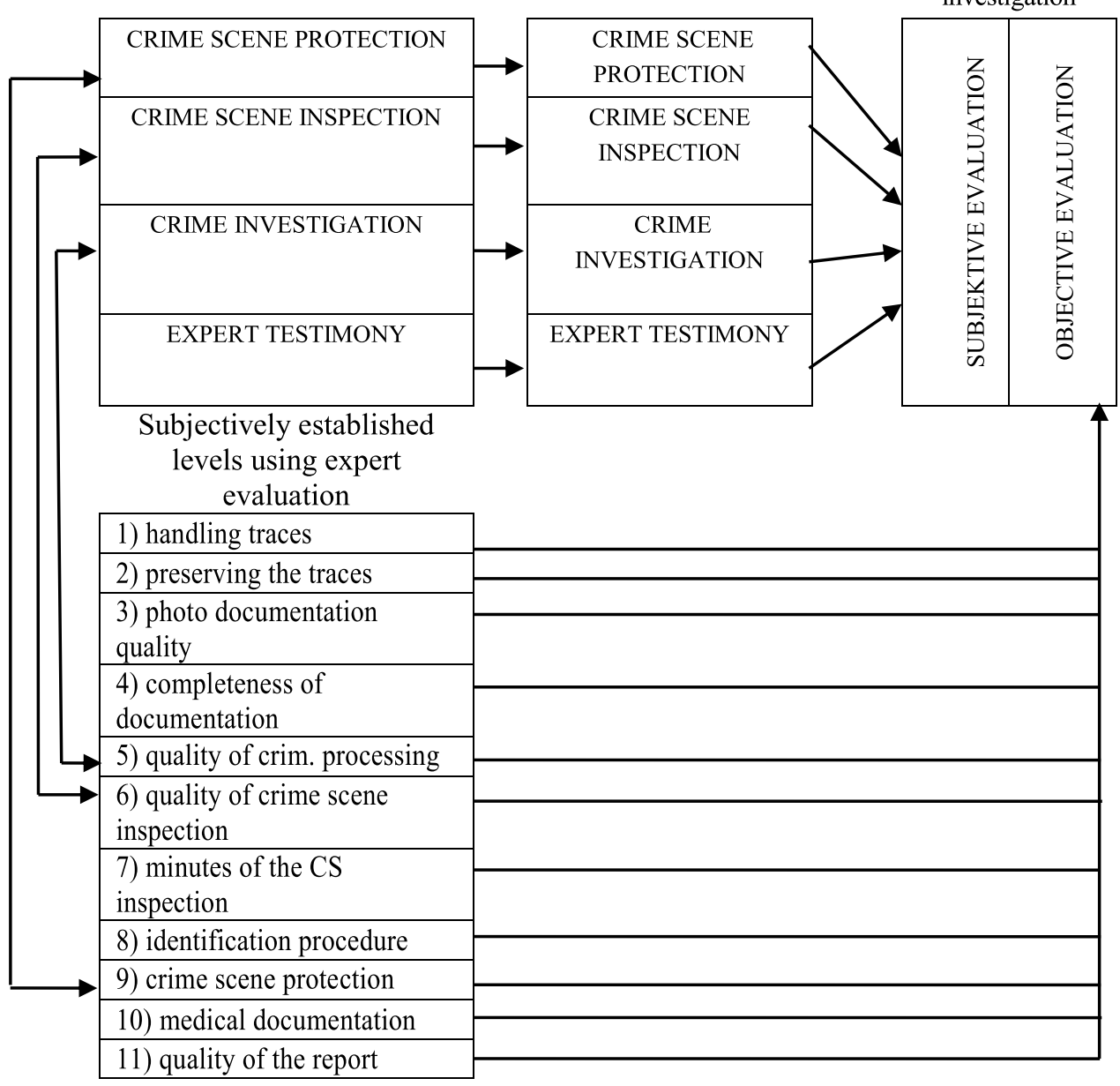

Dijagram 1 - An outline of the research of the influence of crime investigating procedures on the quality and efficiency of rape crimes

The above research plan shows that processing the results by an explanatory analysis strives to establish causal effects of specific manifest 
(subjectively and objectively defined) indicators of the quality and efficiency of the performed procedures and actions involved in crime investigation, whereas functional connection is to be established between specific subjective indicators estimated by the experts and specific manifest variables objectively established by the protocol: crime scene protection, crime scene inspection, and crime investigation.

Therefore the methodological approach of the research comprised the following steps:

1) Collecting data from the valid court decisions of the Municipal Courts in Sarajevo, Mostar, Basic Court in Banja Luka and the Cantonal Court in Sarajevo based on the protocols;

2) Analysing the contents of the written information outlined in the protocols and their coding and recoding so as to obtain adequate data suitable for statistic processing;

3) Expert evaluation of the quality and efficiency of implementation of specific parts of crime investigation procedures (the subjective approach);

4) Establishing the composite variables by summing up the modalities of specific categories obtained by the analysis of the court files (the objective approach);

5) A global expert evaluation of undertaken crime investigating procedures for each individual court case (the subjective approach);

6) An explanatory analysis aimed at establishing direct and indirect effects and contribution of specific elements of criminal procedures to the overall quality and efficiency measured by the subjective method (expert evaluation) and the objective one (cluster analysis).

The purpose of the analytical procedures is to establish the degree of significance of specific steps within the crime investigating procedures and their contribution to the overall quality and efficiency of such procedures and thereby to the timely and just court decisions concerning rape crimes.

\section{Explanatory analysis}

The explanatory analysis strives to achieve the ultimate and the most important aim in social studies - to determine the influence of specific elements, factors and mechanisms which are responsible for certain social phenomena or for the regulation of their tendencies, as well as for explaining why social phenomena are the way they are or why they behave the way they do (Blaikie, 2003). 
Using bi-variant and multi-variant analytical procedures in a regression analysis, an attempt has been made to explain which elements of crime investigating procedures (crime scene protection, crime scene inspection, crime investigation, expert testimony) bear influence on their overall quality and efficiency. Three criterion variables of the overall quality and efficiency will be used: subjective expert evaluation, objectively obtained findings of the cluster analysis, and types of court decisions reached, as an external criterion of success of the performed crime investigating procedures.

\section{Prediction variables - the objective approach}

Prediction variables will be of a composite type. The way they have been obtained is explained in the methodological approach. Graphs $1-4$ illustrate the obtained distributions of results as per each individual composite variable.

KOBEZBM J

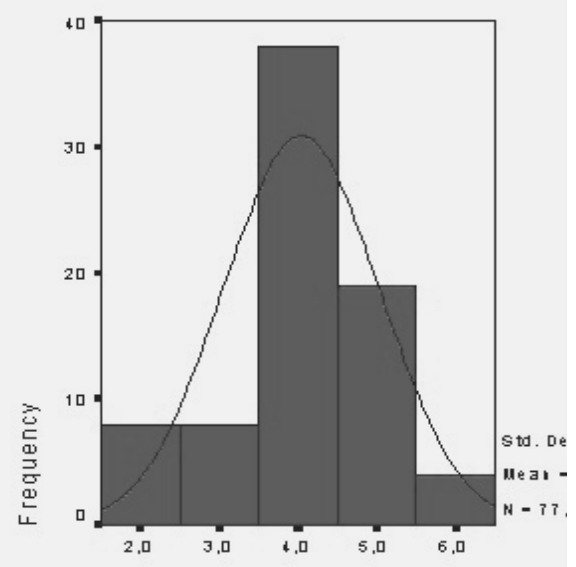

KOBE ZEM J

Graph 1 - Graphic representation of crime scene protection

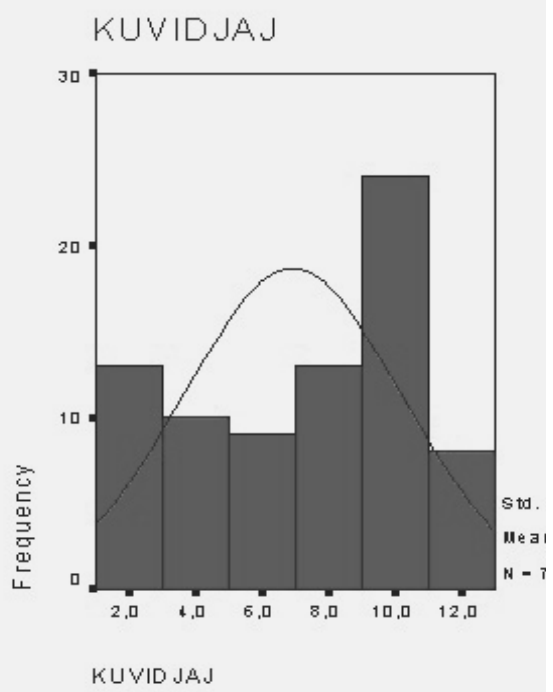

Graph 2 - Graphic representation of the crime scene inspection 


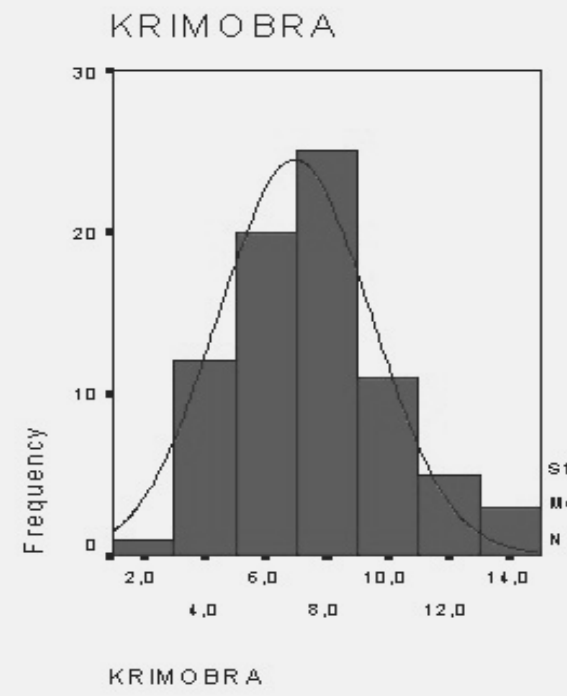

Graph 3 - Graphic representation of crime investigation

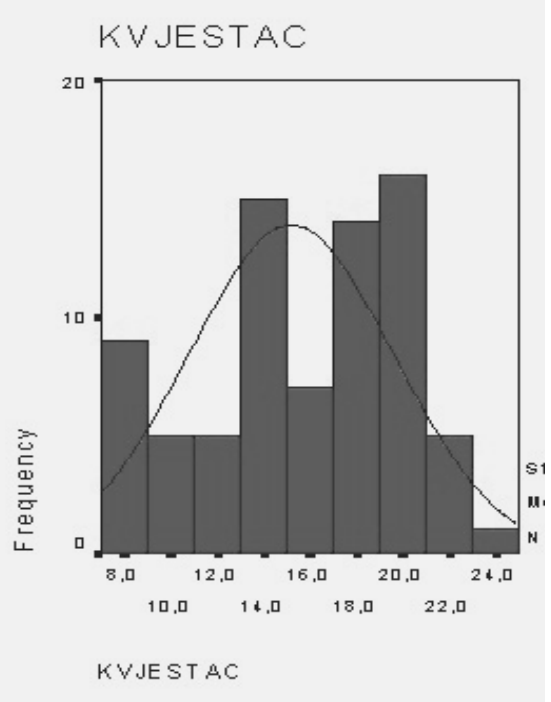

Graph 4 - Graphic representation of expert testimony

The categories range from "not at all or the least" to "the most" values for the presence of certain procedures in the specific analyzed cases. Thus, for instance, if a procedure had not been used at all, it was denoted using zero, and if only the elementary mandatory procedure was implemented but was late (e.g. in crime scene protection) or an incomplete team was engaged (in crime scene inspection), or they failed to search an individual or an object (in crime investigation), or the expert testimony by a specialist (e.g. a gynaecologist) was omitted, it means that minimal category was achieved depending on how many specific elementary procedures were omitted.

The most collective categories were achieved in the cases in which a maximum score was achieved on all indicators and types of necessary procedures of the parts of crime investigating procedures.

It is obvious from the analytical representations that the widest range of categories is related to crime investigation, because the scale was constructed using as many as 12 indicators, whereas expertise required 10 indicators, crime scene inspection - 8 , and crime scene protection only 4 indicators. This fact influenced the tendency of normalising results, which was satisfactory with respect to crime investigation processing and expertise, and was significantly weaker for crime scene inspection and protection. 
Bi-variant and multiple regression analyses will be done for all the obtained composite scales of the quality and successfulness of specific elements of crime investigating procedures.

\section{Prediction variables - the subjective approach}

The other approach was used in an attempt to check to what extent a specific relevant step which is required in crime investigation methodology was or was not used in the cases that constituted our sample. This was achieved using independent evaluators, and then an average grade was calculated based on the independently obtained grades given by three evaluators on a scale of ten (wherein level 1 denoted not at all, and 10 denoted the most applied procedures and steps). The following graphic representations in graphs $5-15$ show the obtained distributions of grades by the experts.

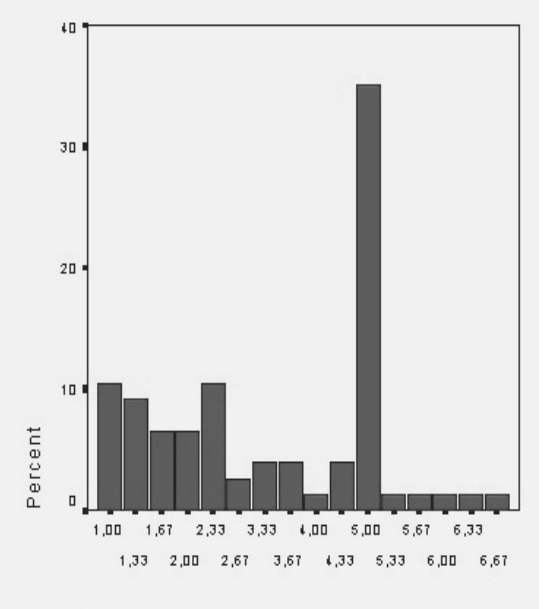

Graph 5 - Graphic representation of evaluation of handling traces;

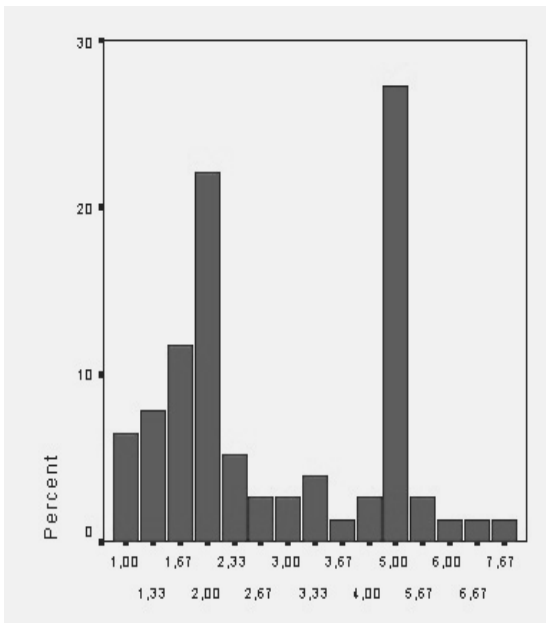

Graph 6 - Graphic representation of evaluation of the manner of evidence preservation 


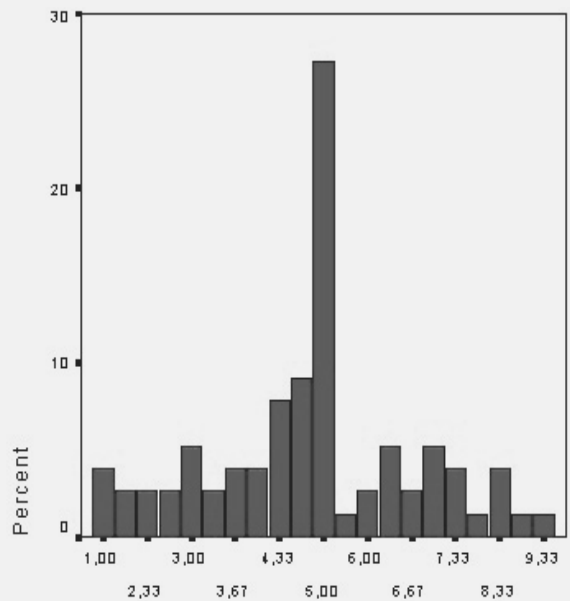

ABCSR V 3

\section{Graph 7 - Graphic representation of} evaluation of the quality of photo documentation

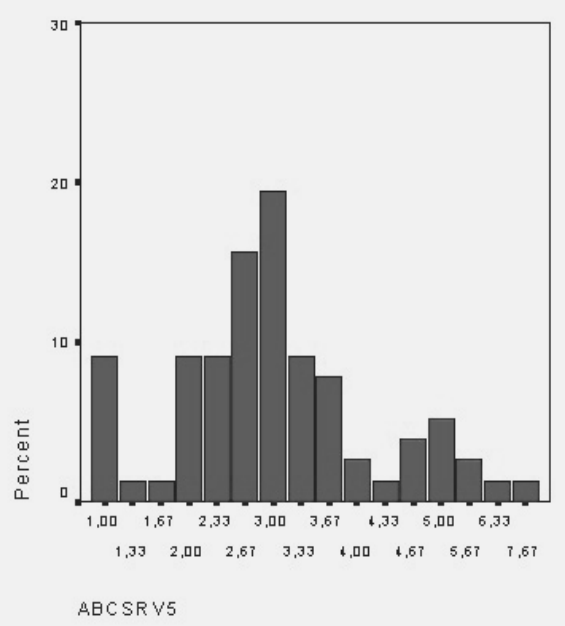

Graph 9 - Graphic representation of evaluation of the quality of crime investigation

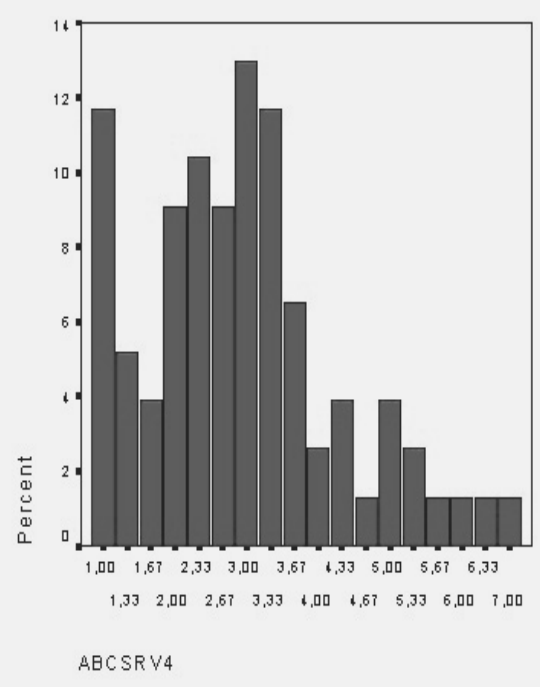

Graph 8 - Graphic representation of evaluation of completeness of documentation

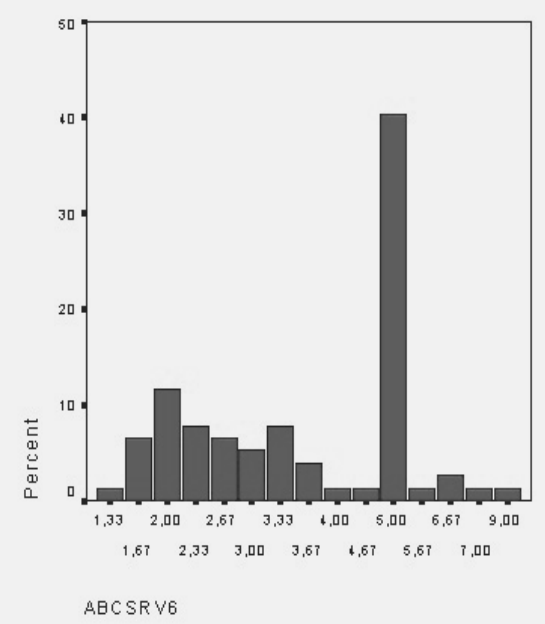

Graph 10 - Graphic representation of evaluation of quality of crime scene inspection 
Analysis of Quality and Efficiency of Crime Investigation Procedures in Processing the Criminal...

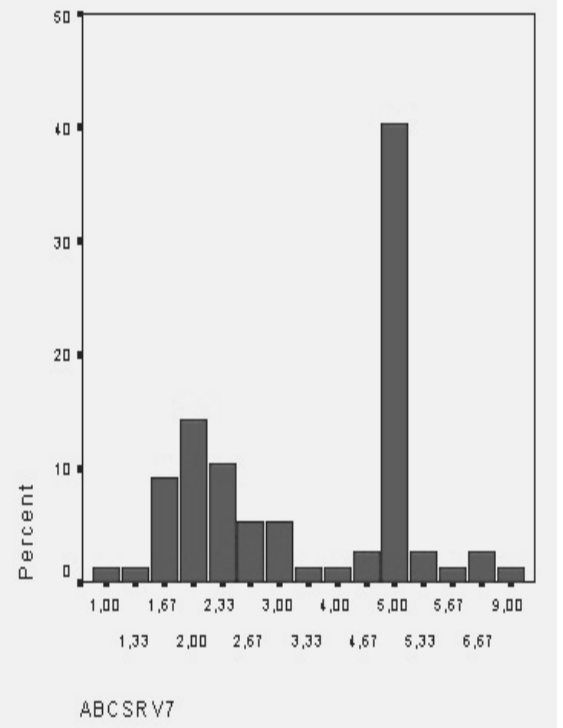

Graph 11 - Graphic representation of evaluation of the minutes of the CS inspection

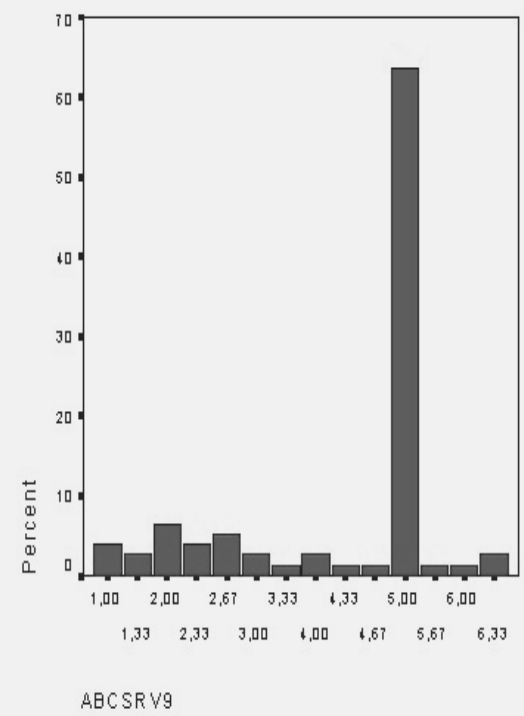

Graph 13 - Graphic representation of evaluation of crime scene protection

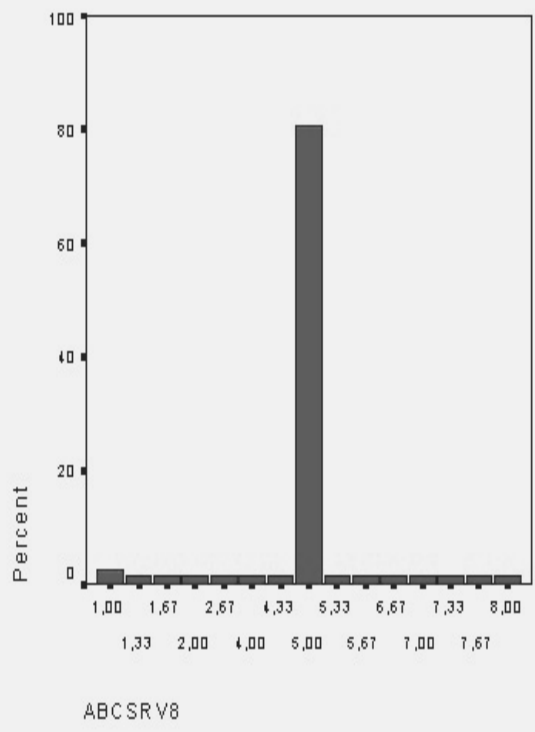

Graph 12 - Graphic representation of the evaluation of identification procedure

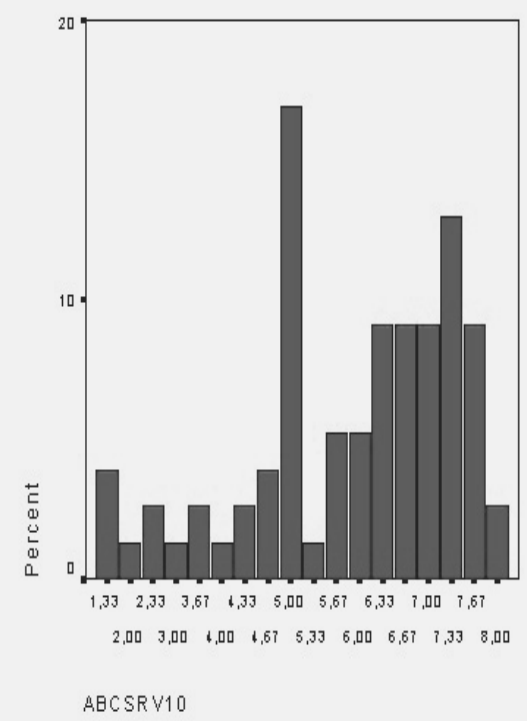

Graph 14 - Graphic representation of evaluation of medical documentation 


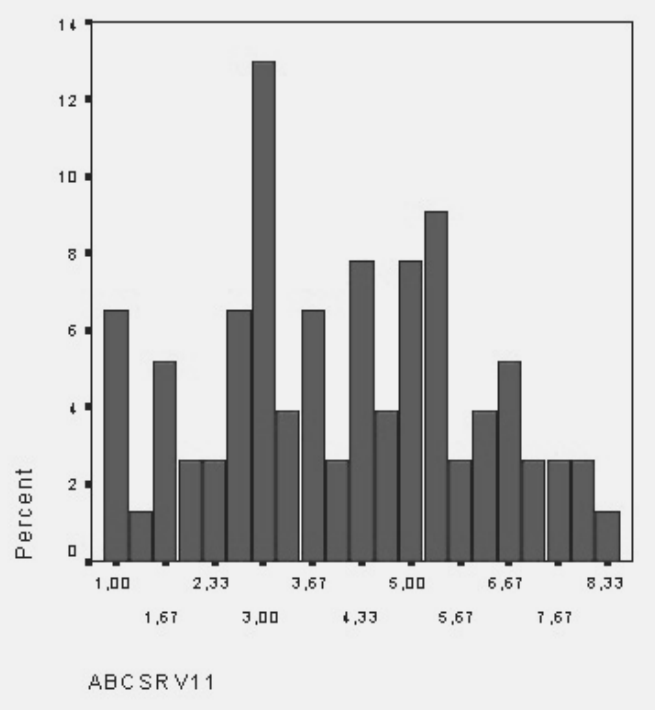

Graph 15 - Graphic representation of evaluation of the quality of the report

The presented distribution of average grades shows a satisfactory variability ranging from the lowest, medium to high values on a scale from 1 to 10 , with a significant part showing tendency towards bimodality since the grades tend to group on lower and higher values of the scale. This is shown in graphs 5, 6, 10, and 11. It means that as regards these areas of crime investigating procedures, the experts evaluators distinguished well between bad and good cases. Conversely, graphic representations in graphs 12 (identification procedure) and 13 (crime scene protection) showed no satisfactory differentiation. The distributions in the remaining graphic representations in graphs $7,8,9,14$, and 15 show a tendency towards more or less normal distribution and this is why a greater emphasis will be placed on the analysis of their regression impact.

\section{Criterion variables}

In keeping with the general plan of research and explanations related to the methodological approach three types of criterion variables were used:

a) Subjective approach - expert evaluations of the overall quality and efficiency of the undertaken crime investigating procedures;

b) Objective approach - using the results of cluster analysis which has given three clearly homogenous and mutually different clusters or groups of rape crime cases. It should be noted that the cluster analy- 
sis included 64 variables with relevant indicators of the quality and efficiency of crime investigating procedures;

c) External criterion - types of court decisions reached in the Municipal Courts in Sarajevo, Mostar, and the Basic Court in Banja Luka and the Cantonal Court in Sarajevo.

For an overview of variability of these criterion variables, the following graphic representations of the obtained distributions are given below:

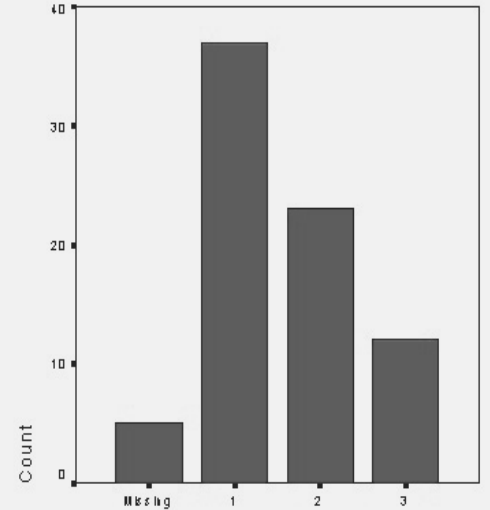

KATEG2

Graph 16 - Graphic representation of the overall expert evaluation of crime investigating procedures

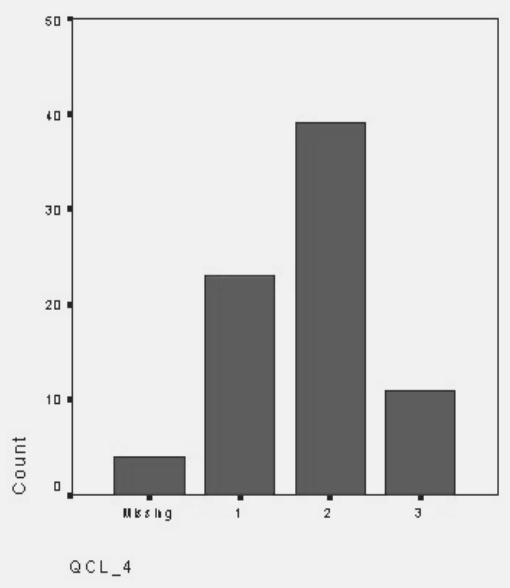

Graph 17 - Graphic representation of obtained clusters

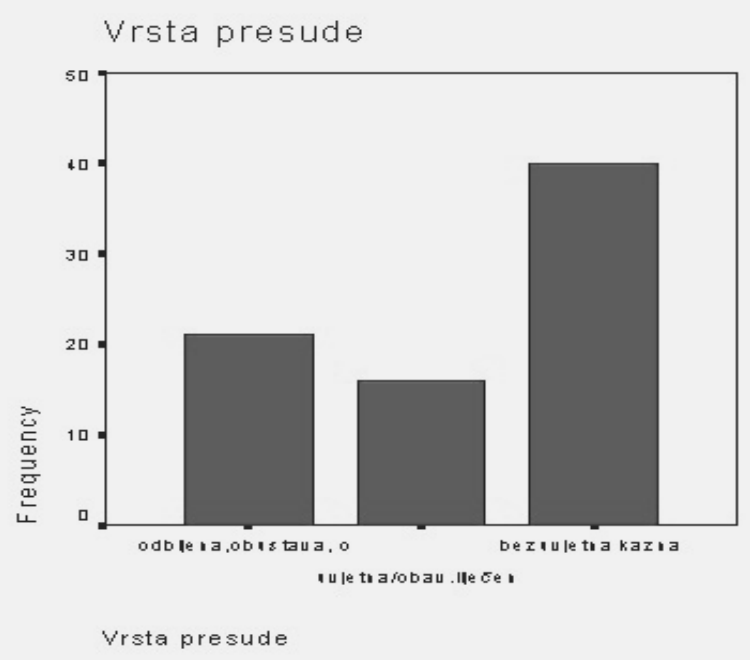

Graph 18 - Graphic representations of court decisions 
EXPERT EVALUATION for all sample cases were classified in three categories: bad 37 or $51.4 \%$, partly good 23 or $31.9 \%$ and good 18 or $16.7 \%$. All court cases were classified in these three categories independently by three evaluators with a high degree of agreement.

THE OBJECTIVE APPROACH using cluster analysis also produced three homogenous groups of cases which differ in the following variables:

- Cluster $2 \mathrm{~N}=41$ or $53.2 \%$ NOT AT ALL OR VERY POORLY processed cases predominantly characterised by: no expert analysis or only one expert analysis, most frequently involving only visual examination, checking for the presence of semen and morphological examination of hairs, absence of medical examination, during the crime scene inspection the team failed to take micro traces, and if they did, the cases mostly contained no record on how they were handled. Searching the persons was partial and the objects were not searched at all. The reports were incomplete, lacking almost any action plans. Forensic medical expertise was not performed.

- Cluster $1 \mathrm{~N}=24$ or $31.2 \$$ SATISFACTORILY processed cases predominantly characterised by the following features: up to three biological expertises, the most frequent among them being the analyses of blood, saliva and semen. Physical examinations were part of the crime scene inspection, micro traces were collected and in part submitted to the police, but it is not known how they were handled further (which in terms of observing a court or investigation file leaves an impression that that the chain of supervision was interrupted, i.e. that the chain of evidence was broken). The search of individuals was performed in most cases but the search of premises occurred only occasionally. The reports partially suggest action plans. Forensic medical examinations were performed for the purposes of expert testimony.

- Cluster $3 \mathrm{~N}=12$ or $15.6 \%$ WELL PROCESSED CASES in which more than four expert analyses prevailed and they were of various types (biological, chemical, mechanoscopic), primarily involving the methods of analysing semen, blood, saliva, hair, phosphates and amylases. All the cases involved the lifting of micro traces, forensic medical examinations and forensic psychiatric expertise. Physical examination of the victims and suspects was part of the crime scene inspection and the CSI teams were complete.

These three homogenous groups of the studied cases obtained by the cluster analysis differ significantly in the quality and efficiency of the performed crime investigation procedures, especially in the elements comprised in crime scene investigation and expertise. 
THE TYPE OF COURT DECISION represents an external criterion that may be used to measure the quality and efficiency of crime investigation procedures. Depending on the degree of relatedness of individual elements of crime investigation procedures with the certain type of court decision: dropped charges, acquittals (18 or $23.8 \%$ ), conditional sentences (17 or $22.0 \%$ ) and unconditional sentences (42 or $54.6 \%$ ), it is possible to speak about the prognostic validity of certain predictors of crime investigation procedures.

\section{Regression analysis of the impact of subjective estimates as predictors on the criterion variable of the overall quality and efficiency of crime investigation procedures}

The first criterion variable of expert evaluations of the overall quality and efficiency of the undertaken crime investigation procedures.

The regression coefficients $R$ indicate that only 4 out of 11 types of evaluation of specific steps and actions significantly influenced the overall evaluation of the quality and efficiency of crime investigating procedures in the cases of rape crimes and these included: the completeness of photo documentation which is reflected in the quality of the report and crime investigation which is most obviously influenced by the identification procedure.

Multiple regression analyses of all predictors resulted in the multiple regression coefficient $\mathrm{R}=0.701$ which is a very high level of correlation of this group of predictors and which explains $49.1 \%$ of the total variance of all results for the quality and efficiency of crime investigating procedures when the quality and efficiency are established by expert evaluation of the degree in which the specific cases involved steps and actions envisaged by crime investigation methodology.

The regression coefficients $R$ indicate that only 4 out of 11 types of evaluation of specific steps and actions significantly influenced the overall evaluation of the quality and efficiency of crime investigating procedures in the cases of rape crimes and these included: the completeness of photo documentation which is reflected in the quality of the report and crime investigation which is most obviously influenced by the identification procedure. 


\section{Diagram 2 - Regression impact}

EVALUATION OF INDIVIDUAL

CRITERION

ELEMENTS OF CRIME

INVESTIGATION PROCEDURES

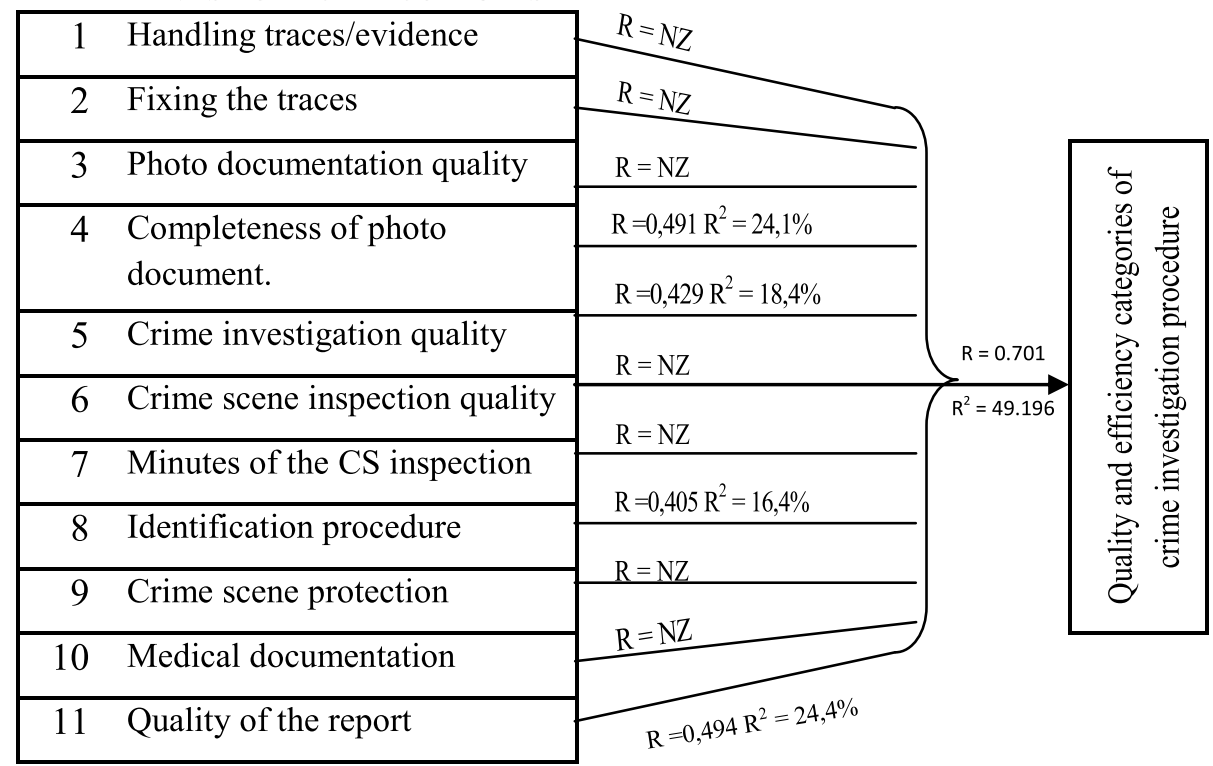

Multiple regression analyses of all predictors resulted in the multiple regression coefficient $\mathrm{R}=0.701$ which is a very high level of correlation of this group of predictors and which explains $49.1 \%$ of the total variance of all results for the quality and efficiency of crime investigating procedures when the quality and efficiency are established by expert evaluation of the degree in which the specific cases involved steps and actions envisaged by crime investigation methodology.

The extent to which the experts retained uniformity of their evaluation criteria is indirectly illustrated by regression analyses with specific elements of crime investigation procedures: crime scene protection, crime scene inspection, crime investigation and expert testimony. 


\section{Regression influence of composite variables on the overall quality and efficiency of crime investigating procedures as estimated by experts}

Diagram 3 - Regression influence and functional relations

PREDICTORS

CRITERION

VARIABLE
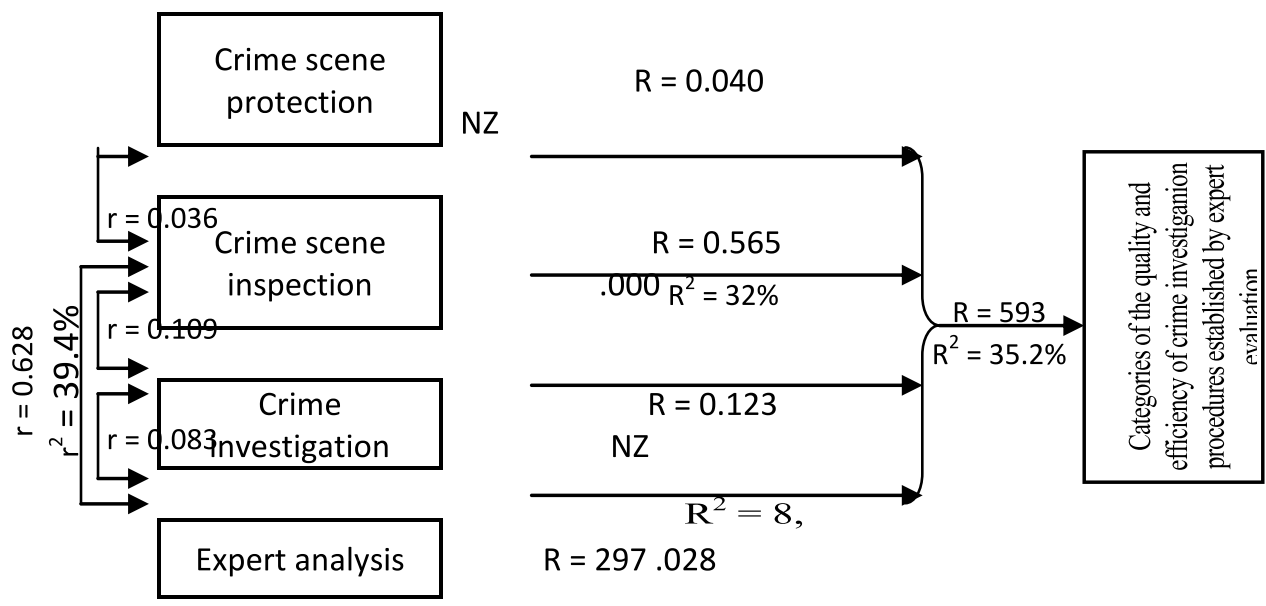

$R=297.028$

The scope, quality and manner of performing crime scene inspection most significantly influence the evaluation of success of crime investigating procedures $(\mathrm{R}=0.565)$ and explain $32 \%$ of the common variance of the result.

EXPERT TESTIMONY rated much lower, but still in a statistically significant measure of $\mathrm{R}=0.297$ which explained $8.8 \%$ of the common variance of the result of the overall evaluation of the undertaken crime investigation procedures.

It is interesting that crime investigation, although it had numerous indicators, did not result in a statistically significant influence on the overall estimate of the quality and efficiency of the undertaken crime investigating procedures in processing rape crimes. It can be noted that the same applies to the absence of influence of the timely crime scene protection.

When checking the mutual relations of the mentioned composite variables, it was found that only the ones of crime scene inspection and expert testimony $(\mathrm{R}=0.628)$ were significantly interrelated. Such a high coefficient of correlation called for a check using the procedure of partial correlation which in fact is the relation between expert testimony and the 
overall evaluation when under control of the crime scene inspection variable. The obtained partial coefficient of correlation of the composite variable of expert testimony and the overall evaluation of the quality and efficiency of the performed crime investigation procedures amounted to $\mathrm{R}=-0.0923$ and suggested there was no connection between estimates of the composite variable of expert testimony and the overall evaluation of the quality and efficiency of the performed crime investigating procedures if the relation between expert testimony and crime scene inspection remains constant. This indicated that we obtained a fake correlation between the composite variable of expert testimony and the overall evaluation of the quality and efficiency of crime investigation procedures $(\mathrm{R}=0.298)$ which occurred due to the fact that expert testimony and crime scene inspection are highly correlated. This could be illustrated by the following diagram:

Diagram 4 -Correlation between expert testimony and crime scene inspection

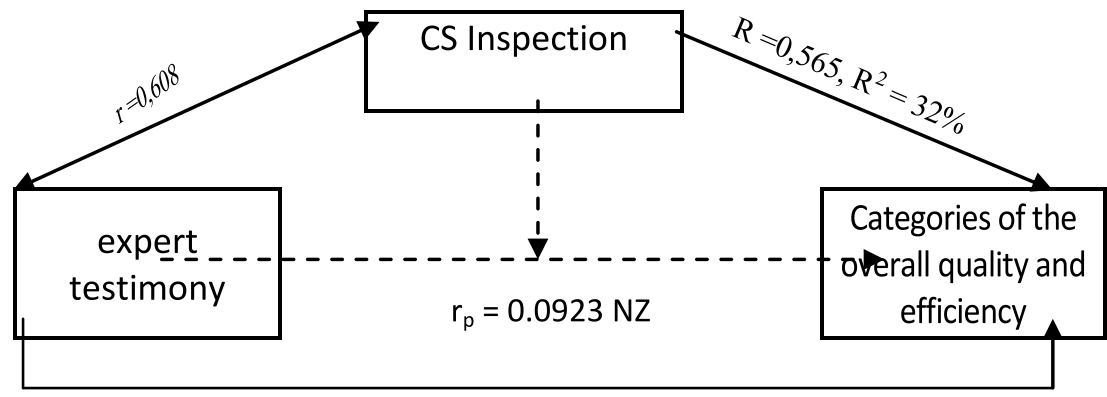

$$
R=0.297, R^{2}=8.8 \%
$$

When defining the category of the overall evaluation of the quality and efficiency of crime investigation procedures, the experts were predominantly guided by the scope, quality and manner of crime scene inspection, and the better its quality and efficiency were, the more it called for more extensive use of expert testimony.

The quality and scope of expert testimony in itself did not have relevant influence of the overall quality and efficiency of crime investigation procedures without the sufficient quality of crime scene inspection in the cases when this was established by subjective expert evaluation based on the overall impression. 


\section{Influence of composite variables on the criterion variable objectively obtained by cluster analysis}

We have so far explored how specific elements of crime investigation procedures expressed through composite variables influence better or worse expert evaluation of the quality and efficiency of the studied court cases related to rape crimes.

The criterion variable which categorized all the cases which were subject of this study, because it was based on a subjective criterion dimension, could show a systematic aberration due to the personal equation of the evaluator which was moderated by calculating their average grades and using such results of average grades in the regression analysis.

In the following survey, we shall use the criterion variable objectively obtained by means of a cluster analysis, which yielded three very interpretable clusters: cases that were very poorly processed or not processed at all (cluster 2), satisfactorily processed cases (cluster 1) and well processed cases (cluster 3).

These clusters are not identical with the categories of expert evaluation of the overall efficiency and quality of the studied cases which the experts categorized as bad, partly good and good. This can be seen in the following contingencies.

The contingency coefficient $\mathrm{CC}=0.352$ indicates less significant association of the subjective expert evaluation and objectively homogenized (categorized) cases.

The association tendency $(\mathrm{CC}=0.352)$ suggests that lower subjective grades show a significant tendency to the homogenous category of poorly or not at all processed cases, but the tendency of higher grades towards the ones obtained by the cluster analysis was not confirmed.

Hence one can expect that the association match of the composite variables of crime scene protection, crime scene inspection, crime investigation and expert testimony will in part follow the same tendency as the criterion variable of the applied subjective overall expert evaluation.

\section{An overview of contingency analysis of the composite variables and the objective criterion variable resulting from the cluster analysis}

Due to its categorical character, the criterion variable obtained by the cluster analysis could not be used in a linear regression and therefore we had to opt for more convenient nonparametric procedures of contingency analyses.

According to the findings of our research, the composite variable of crime scene protection has no significant relation to any of the clusters. In 
this way the identical tendency was confirmed as the one noted when comparing the data on the composite variable of crime scene protection with the criterion variable of the overall expert evaluation related to the quality and efficiency of the performed crime investigation procedures.

The findings also indicated that the type, scope and manner of crime investigation did not influence the overall quality and efficiency of crime investigating procedures which is reflected in the processing of court cases. Thus the findings also confirmed a tendency identical with the one established when checking associations between the composite variables of crime investigation and the subjective expert evaluation of the evaluated crime investigating procedures.

According to the data established in our study, the contingency coefficient $\mathrm{CC}=0.468$ indicated a significant association of the data related to the composite variable of CRIME SCENE INSPECTION with the homogenous clusters of court cases.

The cluster of poorly or not at all processed cases comprised more than a half $(53.9 \%)$ cases wherein the crime scene inspection was poorly performed or not performed at all, which means that failures in crime scene inspection steps bear a significant effect on the objectively established quality and efficiency of the undertaken crime investigation procedures which were reflected in poorly or not at all processed court cases of rape crimes. If we look for the reasons why the crime scene inspection was performed poorly or not at all, it should be borne in mind that the party responsible for this activity can estimate whether there is the actual need for performing it in a number of ways. The main element for estimating lies in the legal provision pertaining to the crime scene inspection, which emphasizes that it is to be performed when it is necessary to directly perceive facts relevant to the proceedings. The challenge here is to disclose the apparently irrational logic and therefore the crime scene should always be carefully inspected together with its surroundings (Korajlic, 2012). If the authority in charge decides that there is no need to perform a crime scene inspection in order to establish facts of either material or nonmaterial nature, there will be no such inspection. Practice shows that due to vast numbers of criminal offences the crime scene inspection is not performed for some of the offences and only a police note is made in the police department. On the other hand, there will be no crime scene inspection if the authority decides that due to a lapse of time between the perpetration of the criminal offence and the report thereof the crime scene could not have been protected and that the evidence has been destroyed due to atmospheric conditions or physical or chemical processes. It should be 
pointed out that in rape cases the crime scene inspection involves the crime scene but also the bodies ${ }^{2}$ of the parties involved and the related objects.

In addition to this, well-performed crime scene inspection actions and steps significantly contribute to satisfactory and good processing of court cases i.e. they lead to timely and just court decisions. The qualification of crime and the establishment of the type of mens rea (for rape only direct intention counts) will depend on the evaluation of crime scene inspection. Inexperienced crime investigators sometimes may reach conclusions after a very brief inspection of the crime scene. This is a very dangerous practice which may appear even among experienced investigators, which should be a reason for concern. When processing a crime scene, it is vital to be familiar with facts and conclusions. It facilitates a reconstruction of the course of an assault and the perpetrator's modus operandi, suggests certain types of information sources and directs crime investigating procedures in a certain direction. Besides, a certain problem may arise with respect to plurilocalisation of the crime scene, in which case Swanson, Chamelin and Territo (2003) speak about macro and micro crime scenes ${ }^{3}$. It is widely known that crime scene inspection generally as well as in the case of rape crimes can take place in all locations where evidence may be found and facts noted relevant for the preparation as well as for the consequences of the criminal offence, and finally, in places where evidence was concealed or where criminal acts faked (Bojanic, 2004).

Hence, as in the case of the overall (subjective) expert evaluation, crime scene inspection represents the most important part of the crime investigation procedure and determines the quality and efficiency thereof.

According to the analysis, the significance of $\mathrm{x}^{2}$ test directly shows a significant difference between the cases in which expert testimonies were performed well (more of testimonies and of better quality) and the cases in which these testimonies were omitted or inadequately performed.

A particularly significant contingency coefficient speaks of a very high (for this type of analysis) association of the cases with well-performed expertise with their overall objectively established quality. The same degree of association is present in the category of satisfactorily quality and efficient crime investigation procedures.

This finding allows a categorical conclusion that the average or poor expert testimony is a prominently restrictive determinant of the overall success of crime investigation procedures, so that together with crime scene

\footnotetext{
${ }^{2}$ Physical examination of the victim is part of the crime scene inspection only when it is performed by the authority in charge of criminal proceeding (Nikolić-Ristanović, 1982).

${ }^{3}$ Macro crime scenes are of a large scope and include objects such as relevant locations, the bodies of the victim and the suspect, vehicles and other. Micro crime scenes include specific items and parts of evidence related to perpetration of a criminal offence.
} 
inspection activities it represents the most important factor on the variation of which it depends whether and to what extent the report to the prosecutor in charge and later indictment will be complete, documented and evidentially convincing.

\section{The influence of composite variables on the type of court decisions}

It has been mentioned that the type of court decisions reached in the first-degree court represents a kind of external criterion of establishing validity of the performed crime investigation procedures.

It was justifiable to expect the better performance of crime investigating procedures would result in more unconditional convictions, and that the failures or poor quality actions in certain elements of crime investigation procedures would be reflected in an increased number of dropped charges, ceased proceedings, acquitted perpetrators, and conditional sentences.

The combination of the composite variables of crime scene inspection and expert testimony ${ }^{4}$ should confirm or deny the mentioned hypothesis.

According to the obtained data, the association tendency of the wellperformed crime scene inspection actions and more unconditional sentences has been proved. In the categories of very poorly performed crime scene inspection there were $47.6 \%$ of dropped charges, ceased proceeding or acquittals, whereas there was half this number $(22.5 \%)$ of the pronounced unconditional convictions.

An even more prominent tendency was obtained on the data related to combining the composite scale of crime scene inspection and the type of court ruling involving conditional punishment or medical treatment $(62.5 \%)$.

The degree of contingency coefficient $\mathrm{CC}=0.412$ indicated that the aberration in the tendency of association between the well performed crime scene inspection and unconditional sentencing was very significant.

It may therefore be concluded that when the crime scene inspection is performed well the decision of the court unquestionably leads to unconditional sentencing of the perpetrator of this exceptionably violent criminal offence. Conversely, poorly performed crime scene inspection activities significantly increase the odds of the indictments being quashed, the proceedings stopped, and the perpetrators acquitted due to a lack of evidence or punished only conditionally.

According to the findings, expert testimony needs to be in keeping with the requirements of crime investigation procedures. Speaking about

\footnotetext{
${ }^{4}$ Regression impacts were shown for the elements of crime scene inspection and expert testimony, so we decided to check their influence of the type of court decisions.
} 
expert testimony related to crime investigation of the criminal offence of rape, the most frequent expertise refers to body examinations and taking other steps, expert analyses of bodily injuries and forensic medical, psychiatric and psychological expertise. In addition to this, in all cases where there are clues as to the use of drugs and alcohol or other intoxicating substances, toxicological expertise of blood samples is performed and DNA analyses are nowadays routinely performed on the biological materials. In our practice, in case of rapes, forensic medical expertise is most frequently performed by an insight in the medical documentation, whereas psychological and psychiatric ones $^{5}$ are performed in a direct contact with the subject.

The significance of the difference in the type of decisions in well performed expert testimony is reflected in the fact that only $27.0 \%$ of the total number of declined or dropped cases, acquitted perpetrators and conditional sentences and medical treatments were in the category of well and very well performed expert testimonies. Conversely, the majority of similar judicial outcomes resulted from bad, weak or averagely performed expert testimony procedures. This is exactly the opposite of the decisions on unconditional conviction where $65.0 \%$ cases involved good or very good expert testimony. Speaking of bad or poorly conducted expertise, based on the studied cases, it is obvious that forensic medical expertise performed on the basis of medical documentation is almost useless because the documentation on which the testimony is based is in the form of specialist report and rather restricted, containing only the diagnosis and the findings of a gynaecological and obstetric examination, as well as a general overview of the bodily injuries. Injury schemes were not made, so that the forensic medicine experts had only scarce data based on which they could not give clear statements in most cases.

The contingency level $\mathrm{C}=0.489$ indicates that this significant association occurs in the situation of average-quality expert testimony, i.e. the one that is insufficient in the number and type, and in the quality of performance. In other words, even when there are average-quality expert testimonies, the perpetrator has a significantly greater chance to be acquitted because of insufficient evidence, the procedure may be halted or the charges dropped. This means that the court in such circumstances acted in keeping with the institute of in dubio pro reo or pronounced a conditional sentence.

On the other hand, the fact that well and very well performed expert testimony may also acquit the falsely accused suspect and thus contribute to the fairness of the trial is not to be neglected.

\footnotetext{
5 According to Griffiths (1992), any actual diagnosis has to be made by a professional qualified in the area of mental health.
} 


\section{Conclusion}

A crime scene inspection represents the most important part and determines the overall quality and efficiency of the crime investigation procedure. A general conclusion can be drawn that the type of court decision and probably fairness of the trial will depend on the quality and efficiency of the performed crime investigation procedures involving crime scene inspection and expert testimony, as the decisions based on evidence lead to adequate rulings based on physical evidence, which are ensured by the crime scene inspection, whereas the actions of expert testimony secure irrefutable findings. Based on everything aforementioned, the main and the specific hypotheses of the study can be confirmed.

It is only in every other case of rape that a CSI team is formed in accordance with the professional rules of crime investigation and procedural requirements by qualified individuals. Rape crimes are very serious criminal offences and their resolution and establishing facts related to such acts should be based on crime scene inspection performed by all such relevant persons as may be envisaged by the law.

It should be pointed out that in resolving rape crimes, if we are to establish facts of such a case actually and justly, the crime scene inspection demands ever more diversified and rich implementation of achievements of scientific and technical disciplines and tactical and methodological means. If the methodological aspect of crime scene inspection is neglected, it could be reduced merely to passive registration of facts. Diversity of criminal offences and the manners of perpetration typical of contact crimes, as well as variability of their course, call for a diversification of methods and means of performing crime scene inspection.

Finally, it should be noted that crime investigating procedures which precede filing the report with the prosecutor differ in quality and efficiency of undertakes steps and activities where crime scene inspection and expert testimony have been performed. It should also be noted that where there were failures in crime scene inspection and processing, the court decisions involved conditional sentences or acquittals.

\section{References}

1. Aleksić, Ž., Milovanović, Z., (1994). Kriminalistika, Beograd: Partenon.

2. Blaikie, N., (2003.). Analyzing quantitative data, Thousand Oaks, CA: Sage.

3. Bojanić, N., (2004). Kriminalista i sudski medicinar u mjerama prvog zahvata kod rasvjetljavanja silovanja, Kragujevac, Beograd, Zemun: 
Pravni fakultet Kragujevac, Institut za pravne i društvene nauke, Policijska akademija, Viša škola unutrašnjih poslova.

4. Bojanić, N., (2007). Kriminalistička procedura istraživanja kod krivičnog djela silovanja, doktorska disertacija, Sarajevo: Fakultet kriminalističkih nauka.

5. Bošković, M., (1990). Materijalni dokazi u kriminalističkoj obradi. Beograd: Nova prosveta.

6. Carney, T.P., (2004). Practical Investigation of Sex Crimes: A Strategic an Operational Approach, U. S.: CRC Press.

7. Klaić, B., (1984). Rječnik stranih riječi, Zagreb: Nakladni zavod MH.

8. Korajlić, N., (2011). Heuristička kriminalistika. Travnik: Pravni Fakultet.

9. Krivokapić, V. (1996). Kriminalistička taktika, Beograd:VŠUP.

10. Simonović, B., (2004). Kriminalistika, Kragujevac: Pravni fakultet.

11. Marinković, D., (2012). Mesto $i$ uloga žrtve u kriminalističkim istragama silovanja, Bezbednost, god. 54, broj 2, Beograd, str. 220-248.

12. Matijević, M., (2002). Kriminalistička operativa, Banja Luka: VŠUP.

13. Modly, D., Petrović, B., Korajlić, N. (2004). Uvod u kriminalistiku, Sarajevo: Fakultet kriminalističkih nauka.

14. Modly, D., Korajlić, N., (2002). Kriminalistički rječnik, Tešanj: Centar za kulturu i obrazovanje.

15. Pavišić, B., Modly, D., (1999). Kriminalistika, Rijeka: Pravni fakultet.

16. Pavišić, B., (2002). Uvod u kriminalistiku, Zagreb: Policijska akademija.

17. Popović, M., (2010). Krivična dela protiv polne slobode, Bezbednost, god. 52, br. 1, Beograd, str. 109-127.

18. Vodinelić, V., (1985). Kriminalistika - otkrivanje i dokazivanje. Skopje: Fakultet za bezbednost i društvenu samozaštitu.

19. Vodinelić, V., (1996). Kriminalistika, Beograd: Zavod za udžbenike i nastavna sredstva.

20. Swanson C. R., Chamelin, N. C., Territo, L. (2003). Criminal Investigation, $8^{\text {th }}$ Ed. New York: McGraw-Hill co. Inc., USA. 


\section{Analiza utvrđivanja kvaliteta i efikasnosti kriminalističkih procedura kod obrade krivičnog djela silovanja}

Apstrakt: Rad je fokusiran na analizu empirijskih podataka koji se odnose na krivična djela silovanja u Bosni i Hercegovini. Navedena analiza obuhvatila je slučajeve iz tri najveća grada u Bosni i Hercegovini, te stoga treba reći da uzorak nije reprezentativan ali je ilustrativan. U ovom istraživanju, koje za cilj ima analizirati sprovođenje kriminalističkih $i$ procesnih radnji u postupku rasvjetljavanja krivičnog djela silovanja, autor se prvi put koristio subjektivno - objektivnom metodom. Prema nacrtu istraživanja, u procesu obrade rezultata na nivou eksplanacijske analize težilo se utvrđivanju kauzalnih uticaja pojedinih manifestnih pokazatelja (objektivno $i$ subjektivno utvrđenih) kvalitete $i$ efikasnosti obavljenih postupaka i radnji koje predviđaju kriminalističke procedure. Funkcionalna povezanost utvrđivana je između pojedinih subjektivnih indikatora procjene eksperata i protokolom utvrđenih na objektivan način pojedinih manifestnih varijabli, koje su se iskristalisale kao predmet istraživanja: obezbjeđenja lica mjesta, uviđaja i kriminalističke obrade. Osnovni problem $u$ ovom radu obuhvaćen je pitanjem: koji postupci i radnje kriminalističkih procedura značajno utiču na kvalitet $i$ efikasnost predistražnih $i$ istražnih radnji, a koje se onda odražavaju na proces suđenja $i$ donošenja pravosnažnih sudskih odluka za krivična djela silovanja.

Autor na osnovu dobijenih rezultata prezentira određene zaključke. Neupitno je da dobro sprovedene radnje prve intervencije, uviđaj, vještačenje i kriminalistička obrada, opredjeljuju sud pri izricanju bezuslovnih sankcija $u$ vidu zatvorskih kazni, dok nepotpuno sprovedene radnje povećavaju mogućnost odbijanja optužnice. Krajnje ishodište istraživanja je da su $k v a l i t e t$ obavljenih kriminalistickih procedura istraga silovanja $i$ vrsta presude, pa time i pravednost suđenja, $u$ direktnoj vezi.

Ključne riječi: silovanje, kriminalističke procedure, kriminalistička obrada, obezbjeđenje lica mjesta, uviđaj, vještačenje. 